\title{
Article \\ Novel Nonylphenol Polyethoxylated Based Surfactants for Enhanced Oil Recovery for High-Mineralization Carbonate Reservoir
}

\author{
Emil R. Saifullin *, Polina O. Putintseva, Rustam N. Sagirov *, Mikhail A. Varfolomeev *(D, Chengdong Yuan *, \\ Roman S. Pavelyev (D), Sergey A. Nazarychev $\mathbb{D}^{D}$, Aleksei O. Malahov $\mathbb{D}^{\mathbb{D}}$, Lucia Akimushkina, Dmitrii A. Zharkov, \\ Alexey O. Bykov and Ulukbek Mirzakimov
}

Citation: Saifullin, E.R.; Putintseva, P.O.; Sagirov, R.N.; Varfolomeev,

M.A.; Yuan, C.; Pavelyev, R.S.;

Nazarychev, S.A.; Malahov, A.O.; Akimushkina, L.; Zharkov, D.A.; et al. Novel Nonylphenol Polyethoxylated Based Surfactants for Enhanced Oil Recovery for High-Mineralization Carbonate Reservoir. Energies 2022, 15, 961. https://doi.org/10.3390/ en15030961

Academic Editor: Jalel Azaiez

Received: 30 November 2021

Accepted: 6 January 2022

Published: 28 January 2022

Publisher's Note: MDPI stays neutral with regard to jurisdictional claims in published maps and institutional affiliations.

Copyright: (c) 2022 by the authors. Licensee MDPI, Basel, Switzerland. This article is an open access article distributed under the terms and conditions of the Creative Commons Attribution (CC BY) license (https:// creativecommons.org/licenses/by/ $4.0 /)$.

\author{
Department of Petroleum Engineering, Kazan Federal University, 420008 Kazan, Russia; \\ putincevapolina7@gmail.com (P.O.P.); rpavelyev@gmail.com (R.S.P.); nazarichev.sa@gmail.com (S.A.N.); \\ AlOMalahov@kpfu.ru (A.O.M.); sagir.krut@gmail.com (L.A.); DmAZharkov@kpfu.ru (D.A.Z.); \\ ao.bykov21@gmail.com (A.O.B.); mirzakimovqs@gmail.com (U.M.) \\ * Correspondence: EmiRSajfullin@kpfu.ru (E.R.S.); RNSagirov@kpfu.ru (R.N.S.); \\ Mikhail.Varfolomeev@kpfu.ru (M.A.V.); jchengdong@kpfu.ru (C.Y.)
}

\begin{abstract}
Surfactant flooding can mobilize trapped oil and change the wettability of the rock to be more hydrophilic, which increases the oil recovery factor. However, the selection of surfactants is difficult in the case of high salinity conditions. In this work, we synthesized three novel anionicnonionic surfactants based on widely used nonionic surfactant nonylphenol polyethoxylated (NPEO) and evaluated their efficiencies for enhanced oil recovery (EOR) in high salinity water $(20 \% \mathrm{NaCl})$. The modified surfactants showed a decrease in interfacial tension (IFT) up to 10 times compared with the nonionic precursor. All surfactants had changed the wettability of rock to be more hydrophilic according to contact angle measurements. The effectiveness of surfactants was proved by spontaneous imbibition experiments, in which the synthesized surfactants showed a better displacement efficiency and increased oil production by 1.5-2 times. Filtration experiments showed an increase in oil recovery factor by $2-2.5$ times in comparison with the nonionic NPEO. These promising results prove that the synthesis of new surfactants by modifying NPEO is successful and indicate that these novel surfactants have a great potential for EOR in high salinity reservoirs.
\end{abstract}

Keywords: surfactants; surfactant-flooding; EOR; high-salinity; carbonate reservoirs

\section{Introduction}

The use of enhanced oil recovery (EOR) methods can extend the production lifetime of mature oilfields in traditional production regions as the oil reservoir becomes depleted and more difficult to recover $[1,2]$. The use of novel surfactants created for individual reservoir conditions can significantly increase oil recovery and affect the wettability of rock and decrease the interfacial tension (IFT) between oil and water [3-8].

Over half of the world-known oil reserves are in carbonate reservoirs [9,10]; the majority of them are heterogeneous and have complicated pore structures. Additionally, most of these carbonate formations contain formation water with a high salinity [11]. Salinity has a significant impact on the surfactant performance and the formation of microemulsion. There are several works conducted to evaluate the effect of salt concentration on the solubility of surfactants in water $[12,13]$. The increase in salts content in the formation water decreases the solubility of surfactants. In microemulsions with high salt concentration, the IFT between the two phases (oil and water) rises as salt content increases [14]. Additionally, it was observed that wettability alteration from oil-wet/mixed-wet to water-wet becomes more difficult in very high salinity and vice versa [15].

Some laboratory screening and field applications of surfactants for carbonate reservoirs with high salinity water were conducted [16-18]. Many types of surfactants were reported, 
including anionic, cationic, and nonionic $[19,20]$, as well as newly created ionic-nonionic, such as guerbet alkoxy carboxylate surfactant [21-23]. It was concluded that despite the fact that nonionic surfactants are the most salt tolerance, they are characterized by low activity in the oil/water interface. However, it is very important to reduce IFT to very low, even ultra-low values, to remobilize the residual oil. Therefore the surfactant should have a high interfacial activity for surfactant flooding [24]. Numerous studies are concerned with special ionic-nonionic surfactants, including modified alkoxy chains (nonionic) by ionic groups, such as alkyl aryl ethoxylated sulphonates and propoxylated sulfate or ethoxylated sulfates $[25,26]$.

In order to improve the interfacial activity of nonionic surfactants, it is necessary to synthesize novel surfactants based on some nonionic surfactants with relatively high activity. Nonylphenol polyethoxylated (NPEO) are nonionic surfactants that are widely used in manufacturing antioxidants, lubricating oil additives, laundry and detergents, emulsifiers, and solubilizers [27], as well as in EOR applications [28]. They were tested under harsh conditions (high salinity and temperature) in conjunction with a cationic surfactant [29]. In addition, NPEO surfactant is stable at very high reservoir salinity [30].

Modification of NPEO by ionic groups can improve surfactant activity that helps to decrease the oil/water IFT and change wettability, and thus increasing oil recovery. Therefore, in this work, based on NPEO, we tried to synthesize anionic-nonionic surfactant that will be compatible with highly mineralized formation waters and show high interfacial activity. Three anionic modifications of nonionic surfactant NPEO were synthesized and investigated for high-mineralization conditions. In contrast to other works focusing on the study of separate surfactant properties, complex laboratory tests were also carried out in this work. The effectiveness of the new anionic-nonionic surfactants was evaluated by studying their ability to reduce IFT and alter the wettability of carbonate rock. Two main mechanisms of oil displacement were considered by long-term spontaneous imbibition and dynamic filtration experiments.

\section{Experimental Section}

\subsection{Materials}

A nonionic surfactant known as nonylphenol polyethoxylated with an average polyethoxylated length of 6 was used as a precursor (NP6EO). NP6EO with 98\% active content was provided by Nizhnekamskneftekhim (Russia) petrochemical company. Maleic anhydride $(99 \%)$ and sodium bisulfite (99\%) were obtained from Acros Organics BVBA, Belgium. Succinic anhydride (99\%) was purchased from Merck KGaA, Germany. Triethylamine $(99.7 \%)$ was provided by Vecton company, Russia. Additionally, 1,3 propansultone (99\%) was purchased from Alfa Aesar, USA. NaOH (98\%) was provided by Dia.M, Russia. $\mathrm{NaCl}$ was obtained from JSC LenReactiv with a purity of $>99.5 \mathrm{wt} \%$. All chemicals were used without any further purification.

Core plugs are real limestone samples taken from the reservoir of the Bashkirian stage, located in the Tatar Republic. The core plugs were extracted, and then porosity and permeability were determined. For imbibition experiments, samples with porosity of $10-14 \%$ and permeability of $100-140 \mathrm{mD}$ were used. For filtration experiments, cores with a porosity of $12-24 \%$ and permeability of $400-900 \mathrm{mD}$ were chosen.

Crude oil was used after separation by centrifuge to remove water and solid residues. Oil properties were measured by tensiometer (Kruss SDT), gas chromatography (Agilent 7890B), and Stabinger viscometer (Anton Paar SVM-3000) (Table 1). In order to simulate high-salinity conditions, $20 \mathrm{wt} \% \mathrm{NaCl}$ solution was used in all experiments.

\subsection{Surfactant Synthesis}

\subsubsection{Synthesis of NP6EO-UOSN}

NP6EO $(12.36 \mathrm{~g}, 25.53 \mathrm{mmol})$ was weighed in a $100 \mathrm{~mL}$ round bottom flask and stirred at $60{ }^{\circ} \mathrm{C}$ for $30 \mathrm{~min}$, followed by the addition of maleic anhydride $(2.51 \mathrm{~g}, 25.61 \mathrm{mmol})$. Then, the temperature was increased to $90^{\circ} \mathrm{C}$. The reaction was monitored by TLC (using 
ethyl acetate as eluent). After $5 \mathrm{~h}$, intermediate compound 1a was obtained as a yellowish, viscous material. An amount of $3.6 \mathrm{~mL}$ triethylamine was added dropwise into a $100 \mathrm{~mL}$ reaction flask containing $50 \mathrm{~mL}$ DCM (Dichloromethane), compound 1a $(14.87 \mathrm{~g})$, and 1,3 propansultone $(3.14 \mathrm{~g}, 25.64 \mathrm{mmol})$. The mixture was stirred for $8 \mathrm{~h}$ at $25^{\circ} \mathrm{C}$. The yellow viscous material was obtained after solvent removal by a rotatory evaporator. The NP6EO-UOSN was used without any further purification.

Table 1. Crude oil properties.

\begin{tabular}{cc}
\hline Property & Value \\
\hline Average alkane number & $\mathrm{C} 8-\mathrm{C} 14$ \\
Viscosity at $20^{\circ} \mathrm{C}$ & $155.88 \mathrm{mPa} \cdot \mathrm{s}$ \\
Density at $20^{\circ} \mathrm{C}$ & $0.932 \mathrm{~g} / \mathrm{cm}^{3}$ \\
Oil-water interfacial tension at $20^{\circ} \mathrm{C}$ & $26.6 \mathrm{mN} / \mathrm{m}$ \\
\hline
\end{tabular}

\subsubsection{Synthesis of NP6EO-SC}

NPEO6 ( $8.56 \mathrm{~g}, 14.70 \mathrm{mmol})$ and sodium bisulfite $(1.6 \mathrm{~g}, 15.22 \mathrm{mmol})$ were loaded into a $250 \mathrm{~mL}$ flask connected to a water condenser containing $150 \mathrm{~mL}$ of aqueous isopropanol solution $\left(\mathrm{V}_{\text {I-Propanol }}: \mathrm{V}_{\text {water }}=1: 2\right)$. The reagents were stirred for $24 \mathrm{~h}$ at $100^{\circ} \mathrm{C}$. The progress of the reaction was monitored by TLC (using ethyl acetate as eluent). After the completion of the reaction, the solvent was evaporated under reduced pressure in a rotary evaporator. The residual material was washed with hexane, then dried under vacuum in a rotary evaporator to obtain pale yellow viscous material NP6EO-SC.

\subsubsection{Synthesis of NP6EO-CN}

NPEO6 ( $8.56 \mathrm{~g}, 17.68 \mathrm{mmol})$ and succinic anhydride $(1.77 \mathrm{~g}, 17.70 \mathrm{mmol})$ were loaded into a $100 \mathrm{~mL}$ flask containing $40 \mathrm{~mL}$ of DCM (Dichloromethane), then $2.46 \mathrm{~mL}$ triethylamine was added with continuous stirring. The reaction was monitored by TLC (using acetone as eluent). The reaction was continued for $6 \mathrm{~h}$ at $25^{\circ} \mathrm{C}$. The yellow viscous material was obtained after solvent removal by a rotatory evaporator. The NP6EO-CN was used without any further purification.

All synthesis schemes are shown in Figure 1.

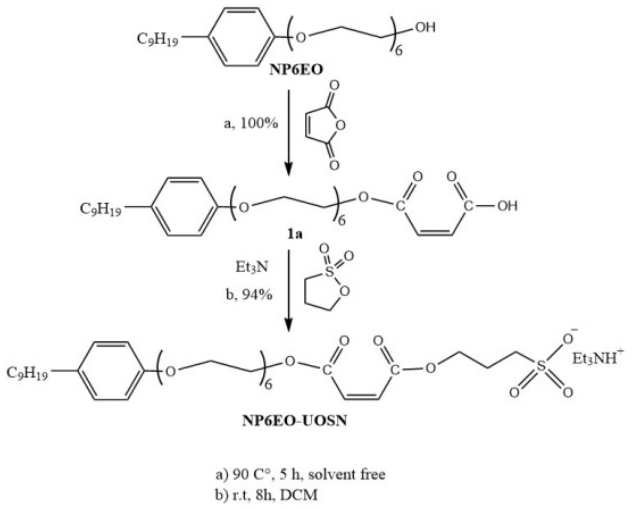

(a)

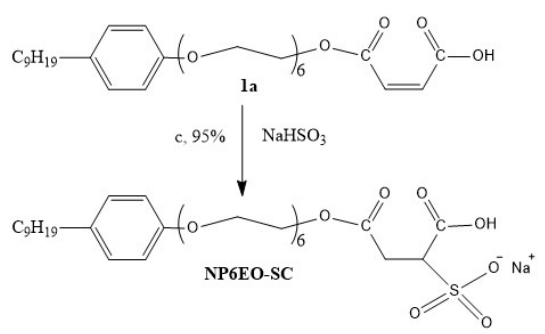

c) $100{ }^{\circ} \mathrm{C}, 24 \mathrm{~h}$, I-Propanol: $\mathrm{H}_{2} \mathrm{O}(1: 2)$

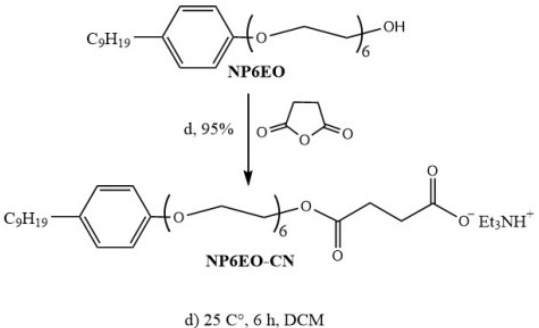

d) $25 \mathrm{C}^{\circ}, 6 \mathrm{~h}, \mathrm{DCM}$ (b) (c)

Figure 1. (a) Synthesis scheme of NP6EO-UOSN; (b) Synthesis scheme of NP6EO-SC; (c) Synthesis scheme of NP6EO-CN.

\subsection{Evaluation of the Surfactants}

\subsubsection{Interfacial Tension (IFT) Measurements}

In order to determine IFT, the spinning drop method (Kruss SDT tensiometer) was used. This allows the estimation of IFT in a wide range of values from high $2 \times 10^{3} \mathrm{mN} / \mathrm{m}$ to ultralow $10^{-6} \mathrm{mN} / \mathrm{m}$. The tensiometer software was used to calculate IFT based on the 
rotation speed, phase densities, and the radius of the stretched drop. All measurements were performed at $20{ }^{\circ} \mathrm{C}$ with a surfactant concentration of $0.3 \%$.

\subsubsection{CMC Determination}

In order to find the optimal concentration of these surfactants, different surfactant concentrations were tested to find out their ability to decrease oil-water IFT [31-33]. The first derivative plotted from surfactant IFT data gave an indication of the critical concentration of forming micelles (CMC). Six different concentrations including $0.025 \%, 0.05 \%, 0.1 \%$, $0.2 \%, 0.3 \%, 0.4 \%$, and $0.5 \%$ were selected for all the surfactants. Surfactant solutions were prepared with water and $20 \%$ of $\mathrm{NaCl}$.

\subsubsection{Wettability Alteration}

The contact angle method is one of the main criteria for evaluating the wetting ability of surfactants. The experiments were carried out using a Dataphysics OCA 15ES device under room conditions.

Core samples were aged in crude oil for 30 days before contact angle measurement. After aging, the surface of core samples was soaked with filter paper to remove excess oil, and the contact angle was measured. One of the carbonate core samples was chosen as the initial measurement by model water, which was used for the subsequent comparison with the action of surfactant formulation. Other core samples were placed in the prepared surfactant solution for 4 and $24 \mathrm{~h}$, followed by dosing a drop of model water on the surface and measuring the contact angle.

\subsubsection{Amott Cells}

For imbibition experiments, surfactants, on the one hand, can increase the hydrophilicity of the rock, thereby reducing the adhesion forces of the oil to displace it; on the other hand, they can reduce the capillary force that mostly behaves as resistance for the oil displacement process.

In order to create initial oil saturation, core samples (Table A2 in Appendix B) with residual water saturation were loaded into a core holder and re-saturated by paraffin ( 2 pore volume injection) at $24{ }^{\circ} \mathrm{C}$. Paraffin was then displaced with oil (3 pore volume injection) at a linear velocity of $5 \mathrm{~m} /$ day. The core samples were then taken out and loaded into a container with crude oil and aged for 30 days at reservoir temperature. After aging, the oil on the surface of cores was cleaned with filter paper for imbibition experiments in Ammot cells. The imbibition process was monitored for $600 \mathrm{~h}$. The oil recovery factor in Ammot cell $\left(O R F_{\text {Ammott }}\right)(1)$ was calculated by Equation (1):

$$
O R F_{\text {Ammott }}=V_{\text {dio }} / V_{\text {io }}
$$

where $V_{d i o}$ is the volume of displaced oil, and $V_{i o}$ is the volume of initial oil in core samples. Four surfactants, i.e., NP6EO, NP6EO-CN, NP6EO-UOSN, and NP6EO-SC, were tested for imbibition experiments. The surfactant solutions $(0.3 \mathrm{wt} \%)$ were prepared with $20 \%$ sodium chloride water.

\subsubsection{Filtration Experiments}

The schematic of the filtration setup is shown in Figure 2. Experiments were carried out using real carbonate cores (Table A1 in Appendix A) under reservoir pressure and temperature, i.e., $50 \mathrm{bar}$ and $25^{\circ} \mathrm{C}$. Overburden pressure was 30 bar higher than reservoir pressure to simulate rock pressure and prevent crossflows. Fluids were injected through a piston cylinder using a plunger hydraulic pump with an accuracy of $0.001 \mathrm{~mL} / \mathrm{min}$. The reservoir pressure was maintained by a piston-type back pressure regulator with a needle valve. The inlet and outlet pressures of the core holder, as well as the differential pressure, were measured using highly sensitive digital pressure transducers (measurement accuracy $0.1 \%)$. Pressure data were continuously recorded online by a computer. 


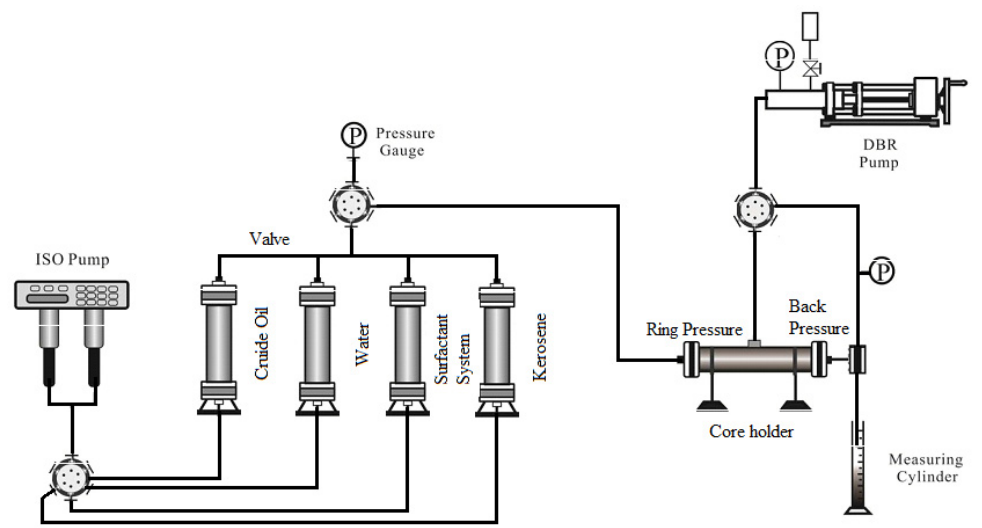

Figure 2. Schematic diagram of water flooding and surfactant flooding experiments.

The experiment was carried out in three stages:

First, cores were saturated with model water (20 wt $\% \mathrm{NaCl}$ solution), and the absolute water permeability was measured. Then cores were saturated with kerosene in a semipermeable membrane to obtain an irreducible water saturation.

Secondly, kerosene was pumped into cores to create reservoir pressure. The cores were then saturated with crude oil (about 4 pore volume (PV) injection) to create initial oil saturation. The injection flow rate was $0.2 \mathrm{~mL} / \mathrm{min}$. Saturated cores were aged for $16 \mathrm{~h}$ in the filtration unit under reservoir conditions.

Finally, the cores were displaced by model water $(0.2 \mathrm{~mL} / \mathrm{min})$ until $100 \%$ water cut. Volumes of displaced fluids at the outlet of the core holder were recorded every $0.2 \mathrm{PV}$. Filtration continued until 100\% water was cut at the outlet but not less than 5 PV. Oil recovery factor (ORF), water cut, and changes in the injectivity of the core were calculated.

ORF and initial injectivity $\left(I_{w 1}\right)$ were calculated by Equations (2) and (3), respectively:

$$
\begin{gathered}
\text { ORF }=V_{d o} / V_{i o} \\
I_{w 1}=q \cdot \mu_{w} \cdot L / \Delta P_{1} \cdot k_{w}
\end{gathered}
$$

where $V_{d o}$ is the volume of displaced oil, $V_{i o}$ is the volume of initial oil in core samples, $q$ is the volumetric flow rate of model water, $\mu_{w}$ is the viscosity of model water, $L$ is the length of the core column, $\Delta P_{1}$ is the pressure drop after $100 \%$ water cut at the outlet at water displacement, and $k_{w}$ is the absolute permeability by model water.

After oil displacement by water, $0.3 \mathrm{PV}$ surfactant solution $(0.3 \mathrm{wt} \%)$ was injected with a constant flow rate of $0.2 \mathrm{~mL} / \mathrm{min}$, followed by subsequent water injection $(0.2 \mathrm{~mL} / \mathrm{min})$ until 100\% water was cut at the outlet but not less than 5 PV. Additional oil recovery factor $(O R F A)$ and water injectivity parameter after surfactant treatment $\left(I_{w 2}\right)$ were determined by Equations (4) and (5), respectively:

$$
\begin{gathered}
\text { ORFA }=V_{\text {ado }} / V_{i o} \\
I_{w 2}=q \cdot \mu_{B} \cdot L / \Delta P_{2} \cdot k_{w}
\end{gathered}
$$

where $V_{a o d}$ is the volume of additional displaced oil, and $\Delta P_{2}$ is the pressure drop after $100 \%$ water cut at the outlet after surfactant treatment.

The change in injectivity was estimated as injectivity parameter $\left(I_{c h}\right)$ by Equation (6):

$$
I_{c h}=I_{w 2} / I_{w 1}
$$

In order to highlight the effect of surfactant treatment from the total oil displacement, the coefficient of additionally displaced oil $\left(K_{O R F}\right)$ was determined as shown in Equation (7):

$$
K_{O R F}=O R F A /(O R F+O R F A)
$$




\section{Results and Discussion}

\subsection{IFT Measurements}

The IFT between crude oil and distilled water was $25.78 \mathrm{mN} / \mathrm{m}$. The addition of $20 \%$ $\mathrm{NaCl}$ into the water decreased oil/water IFT to $15.8 \mathrm{mN} / \mathrm{m}$.

Figure 3 shows the dynamic IFT curves as a function of time, and the stabilized IFT values are shown in Table 2 NP6EO reduced the IFT to $0.16 \mathrm{mN} / \mathrm{m}$, about 10 times lower than that reduced by salt water. A much more significant reduction in IFT values was obtained by all the synthesized surfactants in comparison to NP6EO. NP6EO-CN and NP6EO-UOSN showed the best ability to reduce IFT to 10 times less than that obtained by NP6EO, while NP6EO-SC reduced the IFT by only about three times lower in comparison to NP6EO. These lower IFT values mean that the modification of NP6EO by anionic groups was successful, which significantly improved the interfacial activity of NP6EO.

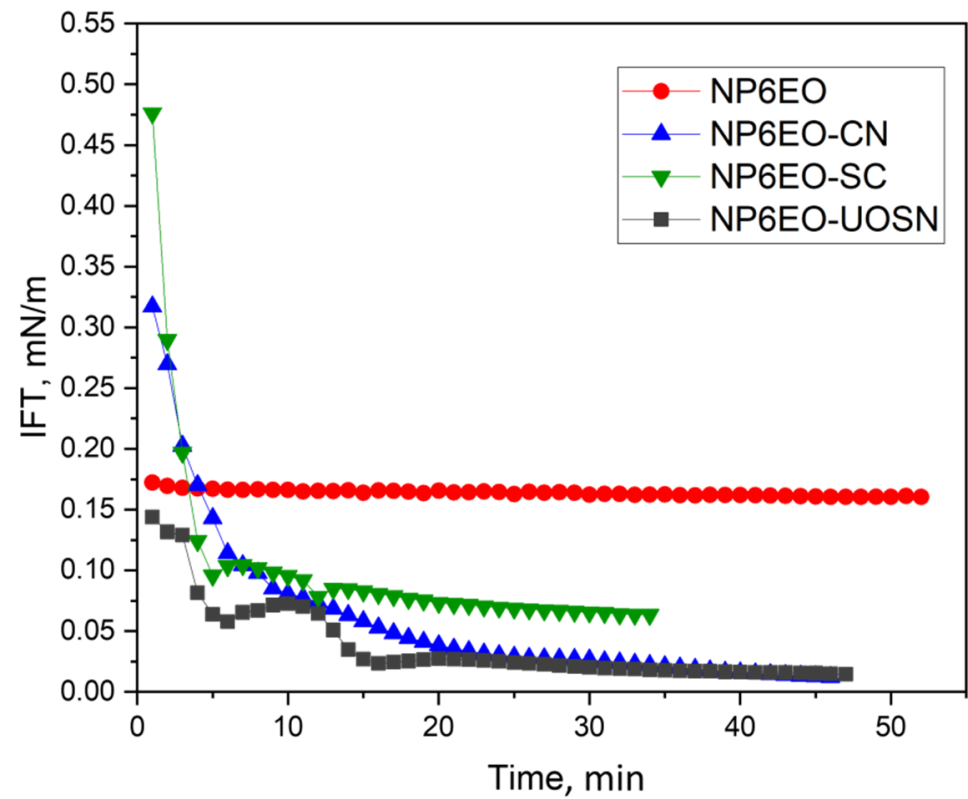

Figure 3. Dynamic interfacial tension between surfactant formulation and crude oil.

Table 2. IFT of surfactant formulations as well as the water used to prepare them.

\begin{tabular}{ccc}
\hline Formulation & Solution & $\begin{array}{c}\text { Stabilized IFT } \\
(\mathbf{m N} / \mathbf{m})\end{array}$ \\
\hline NP6EO & $20 \mathrm{wt} \% \mathrm{NaCl}+0.3 \mathrm{wt} \% \mathrm{NP6EO}$ & 0.16 \\
NP6EO-CN & $20 \mathrm{wt} \% \mathrm{NaCl}+0.3 \mathrm{wt} \% \mathrm{NP} 6 \mathrm{EO}-\mathrm{CN}$ & 0.014 \\
NP6EO-SC & $20 \mathrm{wt} \% \mathrm{NaCl}+0.3 \mathrm{wt} \%(\mathrm{NP} 6 \mathrm{EO}-\mathrm{SC})$ & 0.06 \\
NP6EO-UOSN & $20 \mathrm{wt} \% \mathrm{NaCl}+0.3 \mathrm{wt} \%$ & 0.015 \\
\hline
\end{tabular}

\subsection{CMC Determination}

In the considered range of surfactant concentrations, the lowest IFT value for NP6EO occurred at $0.05 \%$ surfactant concentration. When the concentration was more than $0.05 \%$, the IFT was increased rather than decreased or stayed constant. This phenomenon may be related to a variation in the distribution of surfactant molecules in the oil and water phases induced by increasing surfactant concentration [33]. For the synthesized surfactants, it can be clearly seen that the IFT values become more or less constant after reaching a surfactant concentration of $0.2 \mathrm{wt} \%$ (Figure 4 ), which means that this concentration range is optimal for further studies. In order to achieve a low IFT level for core flooding experiments, $0.3 \mathrm{wt} \%$ concentration was used for all the experiments. 


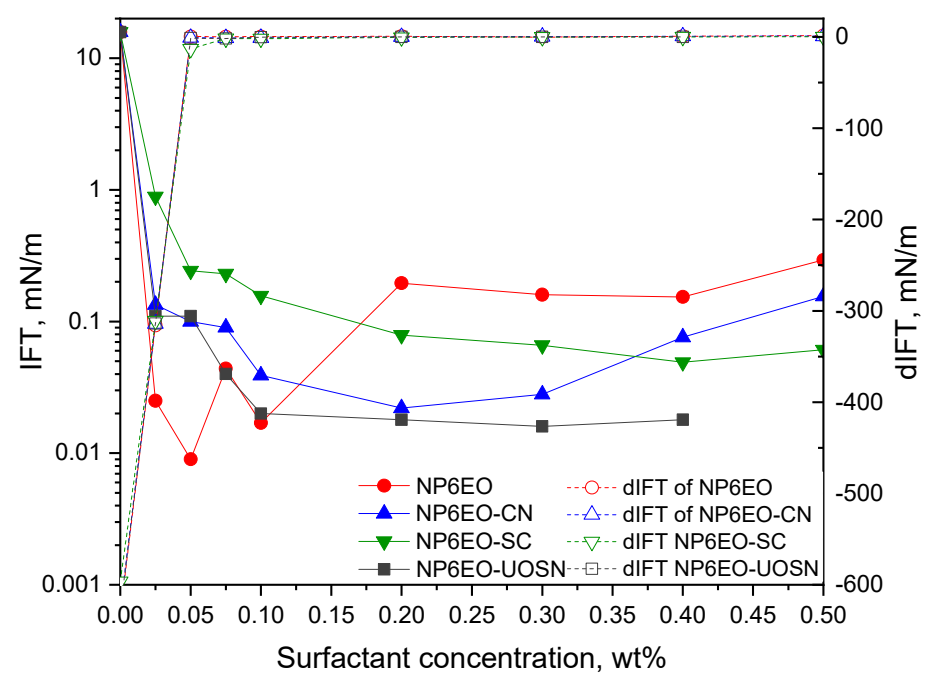

Figure 4. Interfacial tension of NP6EO, NP6EO-CN, NP6EO-SC, NP6EO-UOSN with different concentrations. Twenty percent $\mathrm{NaCl}$ and 1st derivative of IFT function (dIFT).

\subsection{Alteration of Wettability}

The initial contact angles as well as after 4 and $24 \mathrm{~h}$ of soaking in surfactant solution or model water ( $20 \% \mathrm{NaCl}$ solution) were measured by a drop of $20 \% \mathrm{NaCl}$ solution, and the results are shown in Figure 5 and Table 3. As we can see from Table 3, initially core is hydrophilic with the contact angles of about $70^{\circ}$. Aging in model water for $24 \mathrm{~h}$ almost did not change the contact angle. For all the surfactants, after $4 \mathrm{~h}$ aging, the contact angle was decreased by 4-7 times, and after $24 \mathrm{~h}$ of aging, the contact angles were equal to zero in two cases and practically zero in the other two. This means that these surfactants have a good wettability alteration ability, which is favorable for EOR. It is worth noting that NP6EO itself has a good ability to change wettability. It is not difficult for surfactants to change wettability, but it is not easy to reduce IFT to a low or even ultra-low level.

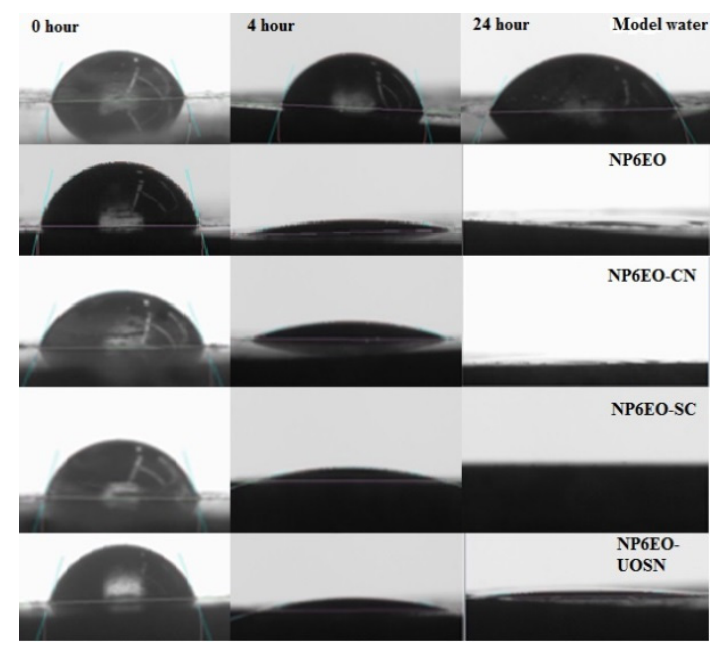

Figure 5. Changes in contact angle after 4 and $24 \mathrm{~h}$ aging of core in surfactant solutions.

Table 3. Results of contact angle study.

\begin{tabular}{|c|c|c|c|}
\hline Formulation & Initial Contact Angle, $^{\circ}$ & Contact Angle after $4 \mathrm{~h},{ }^{\circ}$ & Contact Angle after $24 \mathrm{~h},{ }^{\circ}$ \\
\hline Model water & 71.4 & 74.7 & 61.8 \\
\hline NP6EO & 76.2 & 10.1 & 0 \\
\hline NP6EO-CN & 68.2 & 19.2 & 1.6 \\
\hline NP6EO-SC & 74.1 & 14.8 & 0 \\
\hline NP6EO-UOSN & 69.6 & 15.3 & 2.3 \\
\hline
\end{tabular}




\subsection{Amott Cells}

The core samples were kept in the Amott cells with surfactant solution until there was no oil displacement within 2 days. The best result was shown by NP6EO-SC, while the worst was shown by the nonionic precursor NP6EO (Figure 6). In general, the synthesized surfactants showed the best of $O R F_{\text {Amott }}$ value, increasing it by 1.4 to 2.3 times. NP6EO-SC increased $O R F_{\text {Amott }}$ value 2.3 times, NP6EO-CN 2 times, and NP6EO-UOSN 1.4 times in comparison with NP6EO. Moreover, the oil displacement speed of the synthesized surfactants during spontaneous imbibition is higher than that of NP6EO. It took $288 \mathrm{~h}$ to yield $50 \%$ of the recovered oil by NP6EO, while all synthesized surfactants yielded $50 \%$ of the recovered oil in $48 \mathrm{~h}$. The spontaneous imbibition was also carried out using model water, which almost did not yield any oil during this time. During the imbibition process, the action of the surfactant can be summarized into two aspects. The first is the wettability change, which is a comprehensive result of changes in interfacial tension before oil and water, as well as between water and rock surface [17]. This makes it easier to displace oil. It can be considered as that surfactant significantly reduce the work performed that is required to overcome the adhesion of rock surface to oil, which can be written as $W=\delta_{\text {ow }}(1-\cos \theta)$, where $\delta_{\text {ow }}$ is IFT between oil and water, and $\theta$ is contact angle. However, in Section 3.3, we found that there is no large difference in the wetting ability of these surfactants. Therefore, from this point of view, it can be inferred that wettability alteration might not be the main reason that these synthesized surfactants significantly improved the oil recovery in the imbibition process. In this case, IFT reduction might be the dominant reason. Nevertheless, NP6EO-CN and NP6EO-UOSN, which showed the lowest IFT values, did not give the highest oil recovery. On the one hand, this might be caused by the difference in core samples. On the other hand, this might be related to the complicated action of capillary force in the imbibition process in porous media. Capillary force can play both roles of driving force and resistance in real porous media in the imbibition process, depending on the distribution of oil and water as well as pore structure, etc. [17].

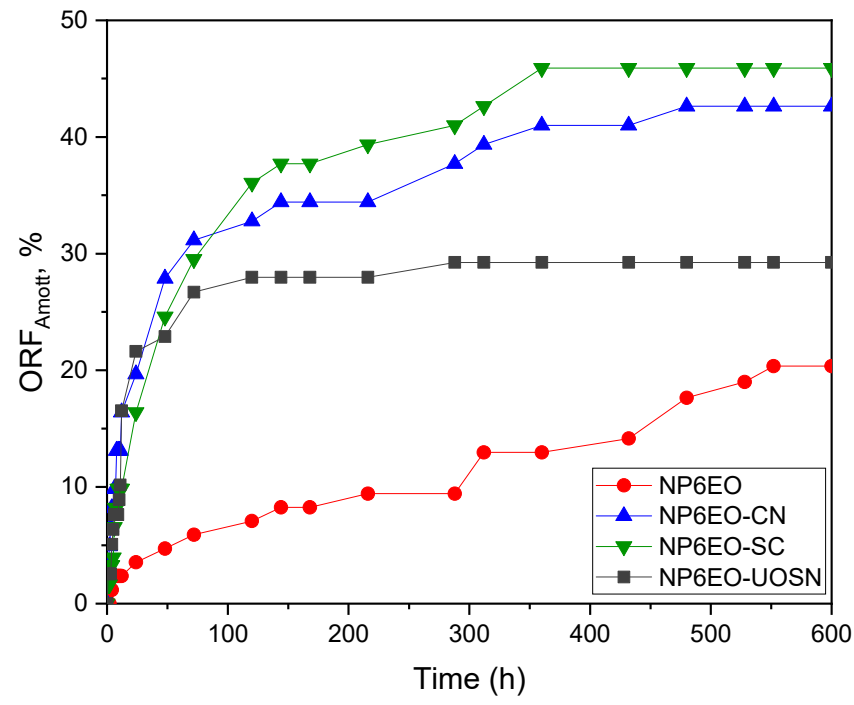

Figure 6. Oil recovery versus time during imbibition process.

\subsection{Filtration Results}

The experimental results are shown in Table 4 and Figures 7-10. According to the experimental data (Table 4), the highest oil displacement efficiency was achieved by surfactant NP6EO-UOSN. This surfactant yielded an ORFA of $16.08 \mathrm{vol} \%$, which is 40 times higher than that achieved by NP6EO. This result is also confirmed by $K_{O R F} 41.91 \mathrm{vol} \%$. It should be noted that all the samples induced a significant decrease in the injectivity of the core samples, which is not good for those reservoirs where water injection is difficult. 
Usually, this decrease in injectivity was caused by the in situ emulsification [33,34], which is favorable for those formations that have strong permeability heterogeneity.

Table 4. The results of experiments.

\begin{tabular}{cccccc}
\hline Value & ORF, $\boldsymbol{\%}$ & ORFA, $\%$ & ORF + ORFA, $\%$ & $\boldsymbol{K}_{\text {ORF }}, \boldsymbol{\%}$ & $\boldsymbol{I}_{\boldsymbol{c h}}$ \\
\hline NP6EO & 20.58 & 1.73 & 22.31 & 7.75 & 0.2384 \\
NP6EO-CN & 45.96 & 7.99 & 53.95 & 14.81 & 0.0157 \\
NP6EO-UOSN & 22.26 & 16.08 & 38.35 & 41.93 & 0.2105 \\
NP6EO-SC & 30.57 & 10.84 & 41.41 & 26.18 & 0.2392 \\
\hline
\end{tabular}

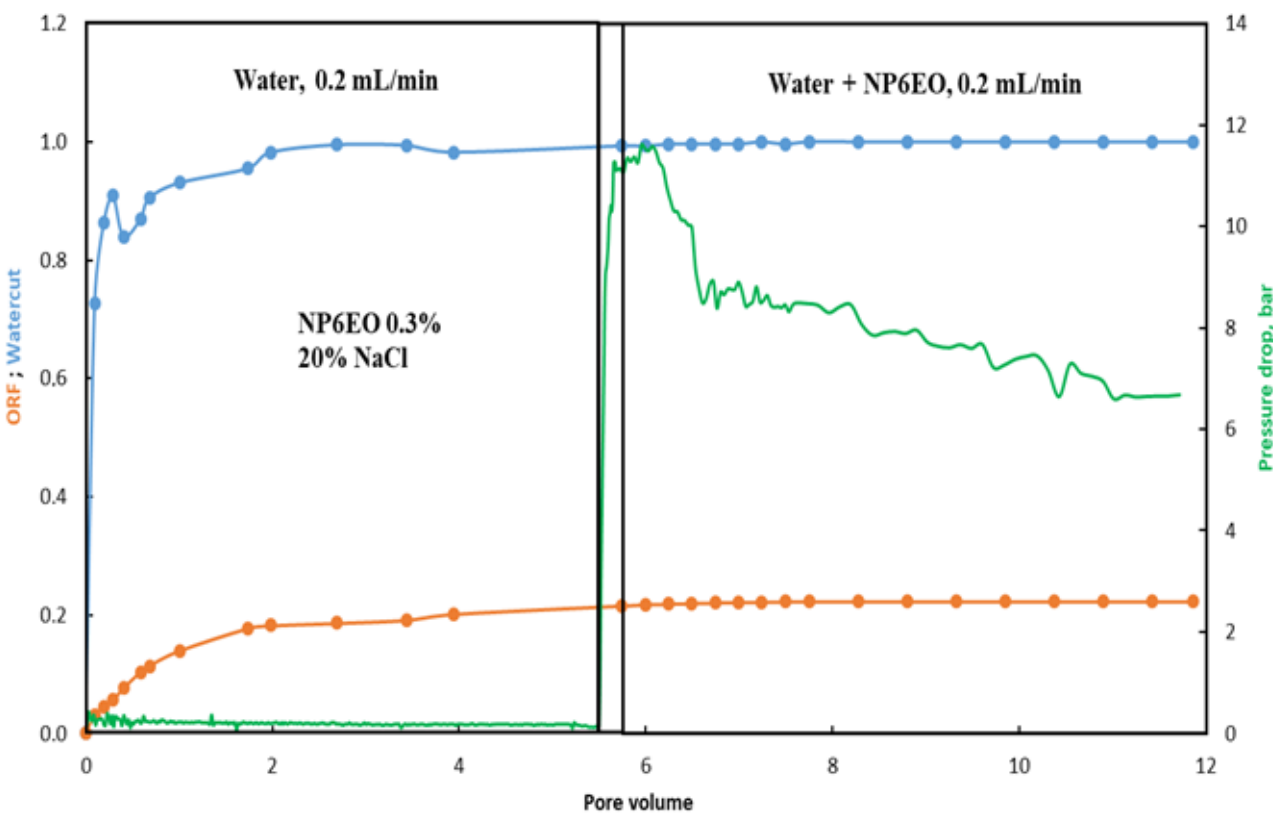

Figure 7. Oil displacement experiment of NP6EO flooding.

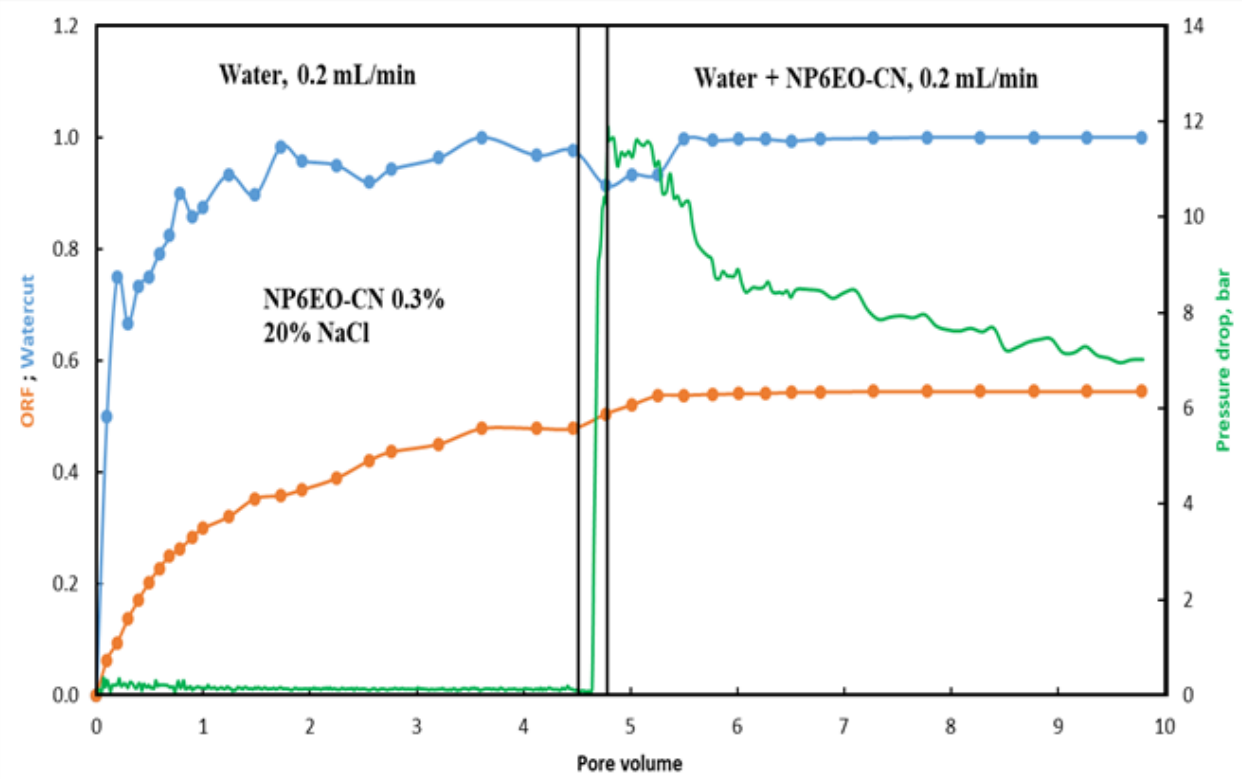

Figure 8. Oil displacement experiment of NP6EO-CN flooding. 


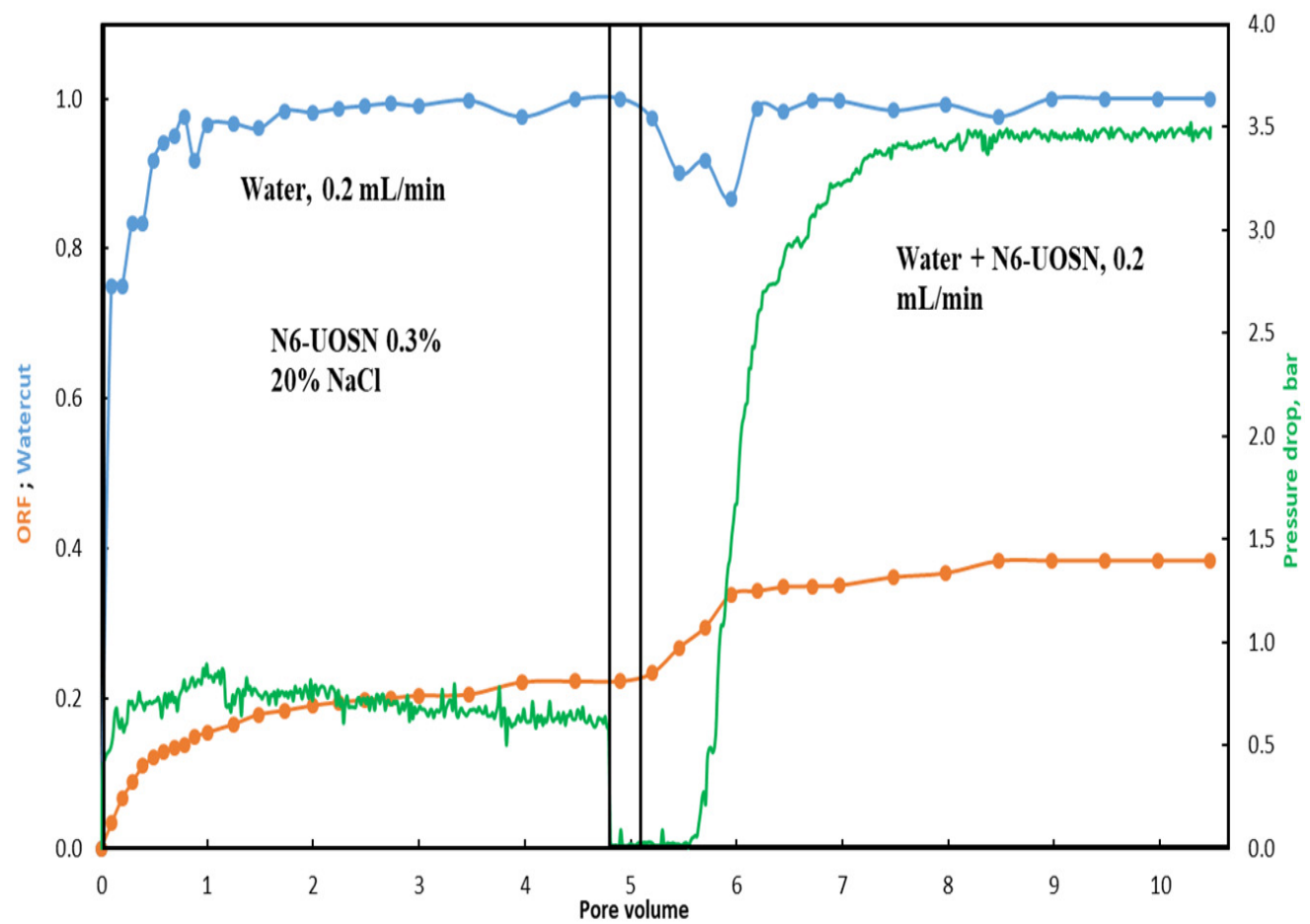

Figure 9. Oil displacement experiment of NP6EO-UOSN flooding.

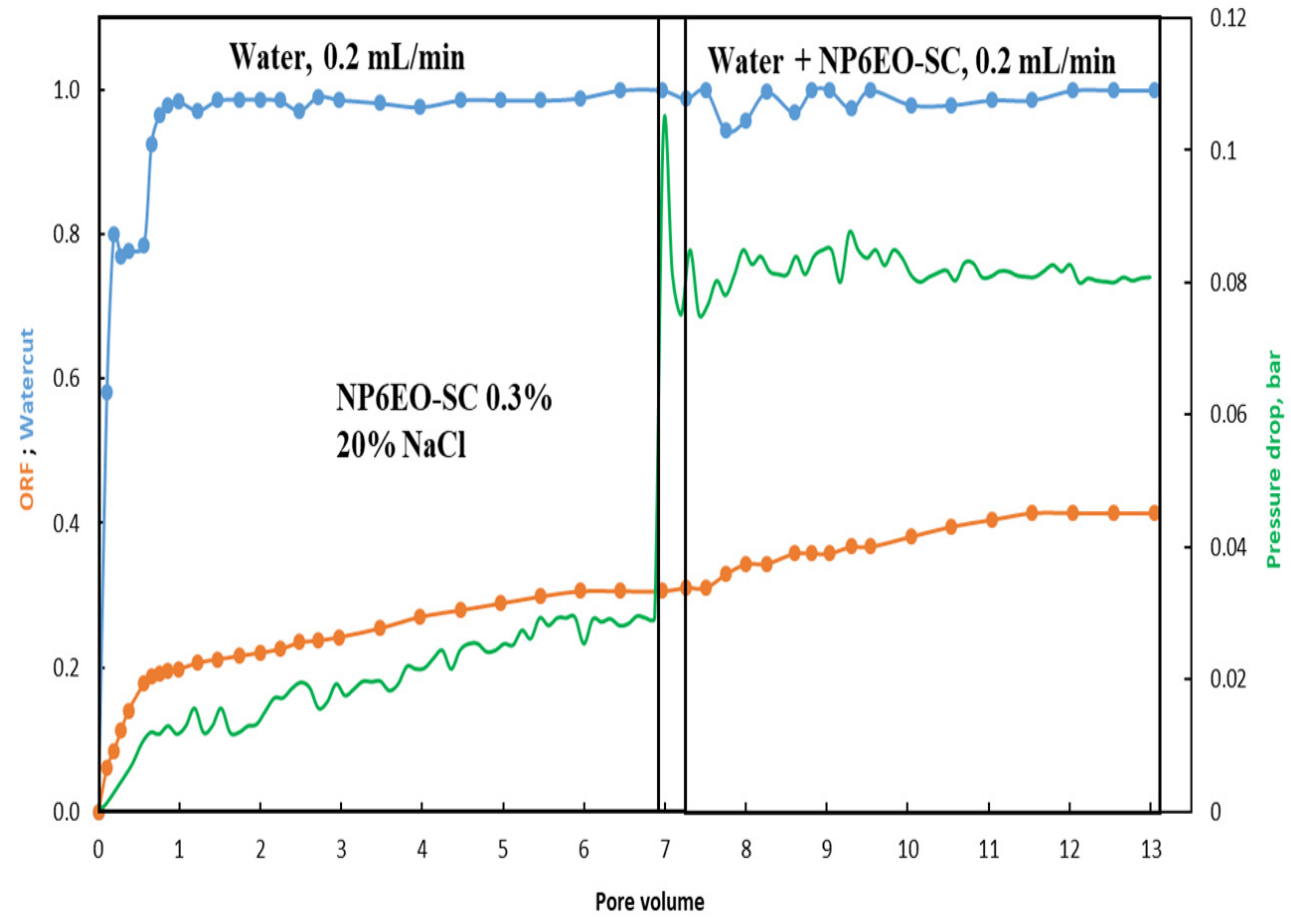

Figure 10. Oil displacement experiment of NP6EO-SC flooding.

In the filtration experiment with NP6EO (Figure 7), the ORF by model water was $20.58 \%$. Surfactant flooding did not show a significant increase in ORFA. The ORFA was only $1.73 \%$ (the lowest in the four experiments). Moreover, the displacement lasted for 5.15 PV to achieve a 100\% water cut. Moreover, the injection of NP6EO had a significant impact on decreasing injectivity $\left(I_{c h}=0.2384\right)$.

In the filtration experiment with NP6EO-CN (Figure 8), the ORF by model water was $45.96 \%$, more than in other experiments. Surfactant flooding did not significantly increase ORFA (only $7.99 \%$ ). The displacement process lasted for 5 PV to achieve a $100 \%$ water cut. 
This sample showed the worst result in injectivity change parameter $\left(I_{c h}=0.0157\right)$. This can be attributed to the possible in situ formation of strong emulsion, which increased the pressure drop and decreased injectivity. Sometimes, an emulsion that is too strong is not favorable for the improvement of microscopic displacement efficiency [34].

In the filtration experiment with surfactant NP6EO-UOSN (Figure 9), the ORF by model water was $22.26 \%$. Flooding with surfactant NP6EO-UOSN gave the highest ORFA $(16.08 \%)$ among the four experiments. The displacement lasted for 5.27 PV to achieve a $100 \%$ water cut. This sample surfactant showed a moderate result in terms of injectivity change parameter $\left(I_{c h}=0.2105\right)$.

In the filtration experiment with surfactant NP6EO-SC (Figure 10), the ORF by model water was $30.57 \%$. The ORFA was $10.84 \%$. Oil displacement lasted for $4.28 \mathrm{PV}$. This sample showed the lowest impact on the injectivity change parameter $\left(I_{c h}=0.2392\right)$.

\section{Conclusions}

Three anionic-nonionic surfactants were synthesized based on nonionic NPEO for high-salinity conditions. Their effectiveness is proved and manifested in:

- $\quad$ Achieved 10 times lower IFT values than NP6EO precursor;

- Yielded a much higher displacement efficiency than the precursor in spontaneous imbibition experiments (NP6EO-SC gives the highest oil displacement efficiency);

- Yielded a higher additional oil recovery than NP6EO in the filtration experiments (NP6EO-UOSN is the most effective one).

In general, all synthesized surfactants showed higher interfacial activity in terms of IFT reduction and oil displacement in comparison with the precursor NP6EO, which proves the successful modification of NP6EO. These promising results imply that these synthesized new surfactants have great potential in EOR in high salinity reservoirs. This work not only provides new surfactant systems, which promotes the application of surfactant flooding to higher salinity conditions, but also gives some basic theories for synthesizing surfactant in terms of which anionic group should be used for high salinity conditions.

Author Contributions: Conceptualization, E.R.S., S.A.N., A.O.M., C.Y., R.N.S. and M.A.V.; methodology, E.R.S., R.N.S. and R.S.P.; formal analysis, R.N.S., P.O.P., D.A.Z., A.O.B. and L.A.; investigation, R.N.S., P.O.P., D.A.Z., A.O.B., L.A. and U.M.; writing-original draft preparation, P.O.P., R.N.S., D.A.Z. and A.O.B.; writing-review and editing, E.R.S., R.N.S. and C.Y.; supervision, E.R.S., C.Y. and M.A.V.; project administration, E.R.S., C.Y. and M.A.V. All authors have read and agreed to the published version of the manuscript.

Funding: This work was supported by the Ministry of Science and Higher Education of the Russian Federation under agreement No. 075-15-2020-931 within the framework of the development program for a world-class Research Center "Efficient development of the global liquid hydrocarbon re-serves".

Institutional Review Board Statement: Not applicable.

Informed Consent Statement: Not applicable.

Data Availability Statement: Not applicable.

Conflicts of Interest: The authors declare no conflict of interest.

\section{Nomenclature}

$\begin{array}{ll}\text { EOR } & \text { Enhanced oil recovery } \\ \text { IFT } & \text { Interfacial tension } \\ \text { CMC } & \text { Critical micelle concentration } \\ \text { ORF } F_{\text {Ammott }} & \text { The oil recovery factor in Ammot cell } \\ V_{\text {dio }} & \text { Volume of displaced oil } \\ V_{\text {io }} & \text { Volume of initial oil in core samples } \\ \text { ORF } & \text { Oil recovery factor }\end{array}$




$\begin{array}{ll}I_{w 1} & \text { Initial injectivity } \\ q & \text { Volumetric flow } \\ \mu_{w} & \text { Viscosity of water } \\ L & \text { Length of core } \\ k_{w} & \text { Absolute permeability by model water } \\ \Delta P_{1} & \text { Pressure drop after full water cut at the outlet at water displacement } \\ \text { ORFA } & \text { Additional oil recovery factor } \\ V_{a o d} & \text { Volume of additional displaced oil } \\ V_{a o d} & \text { Volume of additional displaced oil } \\ \Delta P_{2} & \text { Pressure drop after full water cut at the outlet aftersurfactant treatment } \\ I_{w 2} & \text { Water injectivity parameter after surfactant treatment } \\ I_{c h} & \text { Injectivity parameter } \\ K_{O R F} & \text { Coefficient of additionally displaced oil }\end{array}$

\section{Appendix A}

Table A1. Core for filtration experiment.

\begin{tabular}{|c|c|c|c|c|c|c|c|}
\hline Surfactant & $\begin{array}{c}\text { Core } \\
\text { Samples }\end{array}$ & $\begin{array}{l}\text { Diameter, } \\
\text { mm }\end{array}$ & $\begin{array}{l}\text { Length, } \\
\text { mm }\end{array}$ & Porosity, \% & $\begin{array}{c}\text { Pore } \\
\text { Volume, } \mathrm{cm}^{3}\end{array}$ & $\begin{array}{l}\text { Permeability, } \\
\text { mD }\end{array}$ & $\begin{array}{c}\text { Average } \\
\text { Permeability, } \\
\text { mD }\end{array}$ \\
\hline \multirow{2}{*}{ NP6EO } & 1 & 299 & 500 & 19.55 & 6.86 & 997.2 & \multirow{2}{*}{554.69} \\
\hline & 2 & 299 & 502 & 12.45 & 4.39 & 384.67 & \\
\hline \multirow{2}{*}{ NP6EO-CN } & 3 & 298.6 & 499.9 & 23.47 & 8.21 & 957.98 & \multirow{2}{*}{553.26} \\
\hline & 4 & 298.4 & 500.8 & 11.59 & 4.06 & 389.15 & \\
\hline \multirow{2}{*}{ NP6EO-UOSN } & 5 & 297.8 & 500.7 & 24.51 & 8.54 & 909.26 & \multirow{2}{*}{583.82} \\
\hline & 6 & 298.3 & 502.2 & 10.46 & 3.67 & 430.28 & \\
\hline \multirow{2}{*}{ NP6EO-SC } & 7 & 298.3 & 502.2 & 17.44 & 6.12 & 873.65 & \multirow{2}{*}{618.82} \\
\hline & 8 & 297.8 & 502.6 & 24.37 & 8.53 & 479.17 & \\
\hline
\end{tabular}

\section{Appendix B}

Table A2. Core for spontaneous imbibition experiment.

\begin{tabular}{cccccccc}
\hline Surfactant & $\begin{array}{c}\text { Core } \\
\text { Samples }\end{array}$ & $\begin{array}{c}\text { Diameter, } \\
\mathbf{m m}\end{array}$ & $\begin{array}{c}\text { Length, } \\
\mathbf{m m}\end{array}$ & $\begin{array}{c}\text { Volume, } \\
\mathbf{m L}\end{array}$ & Porosity, \% & $\begin{array}{c}\text { Pore } \\
\text { Volume, } \mathbf{c m}^{\mathbf{3}}\end{array}$ & $\begin{array}{c}\text { Permeability, } \\
\mathbf{m D}\end{array}$ \\
\hline NP6EO & 9 & 4.999 & 2.982 & 34.91 & 13.14 & 4.59 & 124.78 \\
\hline NP6EO-CN & 10 & 5.009 & 2.986 & 35.08 & 12.37 & 4.34 & 131.34 \\
\hline NP6EO-UOSN & 11 & 5.01 & 2.988 & 35.13 & 13.30 & 4.67 & 135.17 \\
\hline NP6EO-SC & 12 & 5.019 & 2.987 & 35.17 & 9.68 & 3.40 & 148.44 \\
\hline Water & 13 & 5.026 & 2.998 & 35.48 & 14.18 & 5.03 & 123.04 \\
\hline
\end{tabular}

\section{References}

1. Manrique, E.J.; Muci, V.E.; Gurfinkel, M.E. EOR Field Experiences in Carbonate Reservoirs in the United States. SPE Reserv. Eval. Eng. 2007, 10, 667-686. [CrossRef]

2. Yang, H.T.; Britton, C.; Liyanage, P.J.; Solairaj, S.; Kim, H.; Nguyen, Q.P.; Weerasooriya, U.; Pope, G.A. Low-Cost, HighPerformance Chemicals for Enhanced Oil Recovery. In Proceedings of the SPE-DOE Improved Oil Recovery Symposium Proceedings, Tulsa, OK, USA, 19-23 April 2010; Volume 2. [CrossRef]

3. Hill, H.; Reisberg, J.; Stegemeier, G. Aqueous Surfactant Systems for Oil Recovery. J. Pet. Technol. 1973, 25, 186-194. [CrossRef]

4. Rao, D.N.; Ayirala, S.C.; Abe, A.A.; Xu, W. Impact of Low-Cost Dilute Surfactants on Wettability and Relative Permeability. In Proceedings of the SPE/DOE Symposium on Improved Oil Recovery, Tulsa, OK, USA, 1-4 April 2006; Volume 1. [CrossRef]

5. Bai, Y.; Wang, Z.; Shang, X.; Dong, C.; Zhao, X.; Liu, P. Experimental Evaluation of a Surfactant/Compound Organic Alkalis Flooding System for Enhanced Oil Recovery. Energy Fuels 2017, 31, 5860-5869. [CrossRef]

6. Jamaloei, B.Y.; Kharrat, R. Analysis of Microscopic Displacement Mechanisms of Dilute Surfactant Flooding in Oil-wet and Water-wet Porous Media. Transp. Porous Media 2009, 81, 1-19. [CrossRef] 
7. Yuan, C.; Pu, W.; Varfolomeev, M.A.; Tan, T.; Zhao, S. Trapped oil in low-permeability zone unswept by water flooding under permeability heterogeneity can be mobilized by ultra-low interfacial tension: EOR mechanism of dilute surfactant flooding proved by low field NMR core flooding and two-parallel core flooding experiments. In Proceedings of the SPE Gas and Oil Technology Showcase and Conference, Dubai, United Arab Emirates, 21-23 October 2019.

8. Cheraghian, G. Improved Heavy Oil Recovery by Nanofluid Surfactant Flooding-An Experimental Study. In Proceedings of the 78th EAGE Conference and Exhibition 2016: Efficient Use of Technology-Unlocking Potential, Vienna, Austria, 29-30 May 2016.

9. Speight, J.G. Rules of Thumb for Petroleum Engineers; John Wiley \& Sons: Hoboken, NJ, USA, 2017. [CrossRef]

10. Akbar, M.; Chakravorty, S.; Russell, S.D.; Al Deeb, M.A.; Efnik, M.R.S.; Thower, R.; Karakhanian, H.; Mohamed, S.S.; Bushara, M.N. Unconventional approach to resolving primary and secondary porosity in Gulf carbonates from conventional logs and borehole images. In Proceedings of the Abu Dhabi International Petroleum Exhibition and Conference, Abu Dhabi, United Arab Emirates, 15-18 October 2000. [CrossRef]

11. Lu, J.; Goudarzi, A.; Chen, P.; Kim, D.H.; Delshad, M.; Mohanty, K.K.; Sepehrnoori, K.; Weerasooriya, U.P.; Pope, G.A. Enhanced oil recovery from high-temperature, high-salinity naturally fractured carbonate reservoirs by surfactant flood. J. Pet. Sci. Eng. 2014, 124, 122-131. [CrossRef]

12. Pal, S.; Mushtaq, M.; Banat, F.; Al Sumaiti, A.M. Review of surfactant-assisted chemical enhanced oil recovery for carbonate reservoirs: Challenges and future perspectives. Pet. Sci. 2018, 15, 77-102. [CrossRef]

13. Araújo, A.A.D.L.; Neto, E.L.D.B.; Filho, O.C.; Foletto, E.L. Influence of sodium chloride on the cloud point of polyethoxylate surfactants and estimation of Flory-Huggins model parameters. Rev. Fac. Ing. Univ. Antioq. 2015, 75, 155-162. [CrossRef]

14. Bourrel, M.; Koukounis, C.; Schechter, R.; Wade, W. Phase and Interfacial Tension Behavior of Nonionic Surfactants. J. Dispers. Sci. Technol. 1980, 1, 13-35. [CrossRef]

15. Dantas, T.N.C.; Soares, A.P.J.; Neto, A.O.W.; Neto, E.L.B. Implementing New Microemulsion Systems in Wettability Inversion and Oil Recovery from Carbonate Reservoirs. Energy Fuels 2014, 28, 6749-6759. [CrossRef]

16. Yuan, C.; Pu, W.; Varfolomeev, M.A.; Mustafin, A.Z.; Tan, T.; Zhao, S.; Liu, R. Sweep improvement options for highly heterogeneous reservoirs with high temperature and ultra-high salinity: A case study in Tarim basin, China. In Proceedings of the SPE Annual Caspian Technical Conference, Baku, Azerbaijan, 5-7 October 2021.

17. Yuan, C.; Pu, W.; Varfolomeev, M.A.; Tan, T.; Timofeeva, A.A.; Sitnov, S.A.; Mustafin, A.Z. Salt-tolerant surfactant for dilute surfactant flooding in high-salinity reservoirs: Residual oil stripping and displacement mechanism and efficiency by ultralow interfacial tension. In Proceedings of the Abu Dhabi International Petroleum Exhibition and Conference, Abu Dhabi, United Arab Emirates, 9-12 November 2020.

18. Varfolomeev, M.A.; Ziniukov, R.A.; Yuan, C.; Khairtdinov, R.K.; Sitnov, S.A.; Sudakov, V.A.; Zhdanov, M.V.; Mustafin, A.Z.; Usmanov, S.A.; Sattarov, A.I.; et al. Optimization of carbonate heavy oil reservoir development using surfactant flooding: From laboratory screening to pilot test. In Proceedings of the SPE Russian Petroleum Technology Conference, Virtual, 12-14 October 2020.

19. Mofrad, S.K.; Dehaghani, A.H.S. An experimental investigation into enhancing oil recovery using smart water combined with anionic and cationic surfactants in carbonate reservoir. Energy Rep. 2020, 6, 543-549. [CrossRef]

20. Sheng, J. Critical review of low-salinity waterflooding. J. Pet. Sci. Eng. 2014, 120, 216-224. [CrossRef]

21. Lu, J.; Liyanage, P.J.; Solairaj, S.; Adkins, S.; Arachchilage, G.P.; Kim, D.H.; Britton, C.; Weerasooriya, U.; Pope, G.A. New surfactant developments for chemical enhanced oil recovery. J. Pet. Sci. Eng. 2014, 120, 94-101. [CrossRef]

22. Chen, H.L.; Lucas, L.R.; Nogaret, L.A.D.; Yang, H.D.; Kenyon, D.E. Laboratory Monitoring of Surfactant Imbibition with Computerized Tomography. SPE Reserv. Eval. Eng. 2001, 4, 16-25. [CrossRef]

23. Xie, X.; Weiss, W.W.; Tong, Z.J.; Morrow, N.R. Improved Oil Recovery from Carbonate Reservoirs by Chemical Stimulation. SPE J. 2005, 10, 276-285. [CrossRef]

24. Amirianshoja, T.; Junin, R.; Idris, A.K.; Rahmani, O. A comparative study of surfactant adsorption by clay minerals. J. Pet. Sci. Eng. 2013, 101, 21-27. [CrossRef]

25. Seethepalli, A.; Adibhatla, B.; Mohanty, K.K. Physicochemical Interactions During Surfactant Flooding of Fractured Carbonate Reservoirs. SPE J. 2004, 9, 411-418. [CrossRef]

26. Hirasaki, G.; Zhang, D.L. Surface Chemistry of Oil Recovery from Fractured, Oil-Wet, Carbonate Formations. SPE J. 2004, 9 , 151-162. [CrossRef]

27. Jianu, C. Synthesis of nonionic-anionic colloidal systems based on alkaline and ammonium $\beta$-nonylphenol polyethyleneoxy ( $\mathrm{n}=3-20)$ propionates/dodecylbenzenesulfonates with prospects for food hygiene. Chem. Cent. J. 2012, 6, 95. [CrossRef]

28. Benomar, S.H. The Analysis of Salt Resistant Surfactants Used in Enhanced Oil Recovery; Sheffield Hallam University: Sheffield, UK, 2001.

29. Sharma, G.; Mohanty, K.K. Wettability Alteration in High-Temperature and High-Salinity Carbonate Reservoirs. SPE J. 2013, 18, 646-655. [CrossRef]

30. Mohan, K. Alkaline Surfactant Flooding for Tight Carbonate Reservoirs. In Proceedings of the SPE Annual Technical Conference and Exhibition, New Orleans, LA, USA, 4-7 October 2009; Volume 7. [CrossRef]

31. Haq, B.; Liu, J.; Liu, K.; Al Shehri, D. The role of biodegradable surfactant in microbial enhanced oil recovery. J. Pet. Sci. Eng. 2020, 189, 106688. [CrossRef]

32. Liu, C.; Wang, Y.; Cui, L.; Zhang, G.; Xu, B. Synthesis, characterization, and properties of acyl glycine, alanine, valine, and leucine derived from vegetable oils and beef tallow. Tenside Surfactants Deterg. 2020, 57, 340-346. [CrossRef] 
33. Yuan, C.; Pu, W.-F.; Wang, X.-C.; Sun, L.; Zhang, Y.-C.; Cheng, S. Effects of Interfacial Tension, Emulsification, and Surfactant Concentration on Oil Recovery in Surfactant Flooding Process for High Temperature and High Salinity Reservoirs. Energy Fuels 2015, 29, 6165-6176. [CrossRef]

34. Pu, W.; Yuan, C.; Hu, W.; Tan, T.; Hui, J.; Zhao, S.; Wang, S.; Tang, Y. Effects of interfacial tension and emulsification on displacement efficiency in dilute surfactant flooding. RSC Adv. 2016, 6, 50640-50649. [CrossRef] 